\title{
Implementation of Community Development and Empowerment of PT. Nusa Mineral Halmahera Through Corporate Social Responsibility Programs
}

\author{
Erland Mouw ${ }^{1}$, Gloria Miagina Palako Djurubassa ${ }^{2}$, Herman Sidete $^{3}$, Dominggus Isak Bitjara ${ }^{4}$ \\ \{erlandm25@gmail.com $\left.{ }^{1}\right\}$ \\ Universitas Halmahera ${ }^{1,2,3,4}$
}

\begin{abstract}
The notion of transparency in Sustainable Development through Corporate Social Responsibility (CSR) has become inconsistent because local governments and communities do not know the amount of budget and programs implemented. This issue made many programs implemented not beneficial to the community. CSR managers who were not transparent in the amount of the budget made a gap with the community. There must be a harmonization between CSR, local governments and communities around the mine in financial management of program implementation.
\end{abstract}

Keywords: Implementation, Program, Corporate Social Responsibility

\section{Introduction}

Newcrest and Antam formed a joint venture in 1994 to conduct a gold search exploration at Gosowong, Halmahera island. In 1997, Newcrest and Antam formed PT Nusa Halmahera Minerals (PTNHM) and Kontrak Karya (the Contract of Work) between the Government of Indonesia and PTNHM which was signed on April 28, 1997. The first gold ore was poured at Gosowong in July 1999. PTNHM always maintains a strong commitment to the local community. At present, PTNHM invests extensively in community initiatives that can benefit from mining activities, helps fulfill community needs and strengthens socio-economic development in the region. The aim of all this is to build and develop an open and constructive approach to community engagement and investment activities. PTNHM's Corporate Social Responsibility (CSR) program is intended to help develop a sustainable economy and improve the quality of life of local communities through collaboration with all stakeholders (local government and the community). One of the participations of the company is to help the community in the form of partnerships known as CSR fund partnerships through CSR funds issued [1]. However, the openness of the implementation of CSR funds management, by the local government and the community, is considered problematic because PT NHM is deliberately not transparent in distributing CSR funds to the community around the mine in North Halmahera Regency, North Maluku Province. So far, the local government has never received reports related to the utilization of CSR funds in stages since 2010-2017.

In addition, many programs have been implemented but not beneficial to the community, for example the construction of virgin coconut oil (VCO) in Makaeling Village, Kao Teluk District, which had been built since 2010 through a CSR program but until now it is not able to function. In fact, most of the people around the mine are coconut farmers, but the factory is 
only built but not functioned as expected. If this coconut oil factory has been functioned, it can be a support for the economy of the surrounding community. Since the factory was built, there was no socialization to the community in Kao Teluk, so even though it was there, the factory was not useful for the community. Even now it has begun to break down and the bush has grown on the factory site.

The number of issues has encouraged this research to analyze the process of implementing community development and empowerment through CSR programs, CSR budget transparency which had experienced ups and downs due to various criticisms and debates due to a considerable number of CSR programs whose implementations were not useful and did not empower the community, and the public and government responses in local context to the realization of CSR programs that were considered not transparent which then caused rejection.

\section{Method}

This type of research was qualitative research, with a descriptive analysis approach. Data was collected through interviews, documentation and observation [2]. In this study basically qualitative descriptive analysis method was used. This method is a process of organizing and sorting data into patterns, categories and units of basic descriptions so that themes and conclusions will be obtained [3]. The data collected in this research process are classified into three types: (1) Data from the North Halmahera Regency Government concerning program documents and their implementation in the community will be collected using some techniques, which are: secondary data collection (documents on program planning and realization of known CSR activity programs) and in-depth interviews (clarification of the background of the selection of program types of activities and problems encountered in the program implementation process); (2). Data from CSR Management in charge of implementing the program, which was collected by: secondary data collection to find out (types of activities carried out and the amount of budget used) and in-depth interviews to find out which implemented programs were able to provide benefits to the community around the mine; (3). Data from the community around the mine concerning the benefits of the program for them. Data analysis was carried out by referring to the stages described by Miles and Huberman which of: data reduction, data presentation and verification and conclusion [4].

\section{Result and Discussion}

\subsection{CSR Program Implementation System}

Program implementation began with socialization activities carried out by CSR fund managers (2007-2016 CSR Department and 2016-2018 Social Performance) to communities around the mine (Kao District, West Kao, North Kao, Kao Teluk, and Malifut) in July-August. The main focus is a sustainable Community Development Program (PPM) with long-term results to support the community.

PTNHM CSR always prioritizes cooperation and communication efforts through meetings and discussions with community leaders and local governments for the success of sustainable community development and empowerment programs. Although normatively the implementation of CSR is driven by an awareness of social responsibility, its implementation is still overshadowed by the positive image of the company. The company in general does not have a strategic plan or a comprehensive blueprint for program implementation [5].

The first stage is that each village through the team (Village Head and 2 Members) makes a proposal in September-October based on the results of the village meeting to be submitted to 
the district which will be examined by the district head in order to filter and anticipate overlap with the local government program. The selected proposals from the district head are submitted to the CSR Team. The next stage of the CSR process is to select each program that is followed by the village to be funded in November-December.

After the proposal is approved to be financed, the budget realization process and program implementation take place in January-June. The activity is carried out by the village by involving the community. Therefore, development financing requires an effort to identify funding capabilities that involve the government and the private sector so that it can provide an appropriate picture for medium-term, and short-term development plans [4]. Furthermore, the successful implementation of CSR programs is the establishment of a clear pattern of relationships among the parties involved.

This will improve the quality of coordination of the implementation of CSR programs. Without a clear pattern of relations among various parties involved in implementing CSR, it is likely that the implementation of the CSR program will not run optimally. Besides that without a clear relationship pattern, the possibility of the CSR program to be sustainable will be reduced [6]. The following shows the CSR program and budget data.

Table 1. CSR Program and Budget

\begin{tabular}{|c|c|c|c|c|c|}
\hline $\begin{array}{l}\text { The Use of } \\
\text { CSR Fund }\end{array}$ & 2013 & 2014 & 2015 & $\begin{array}{l}2016 / \\
2017\end{array}$ & $\begin{array}{l}2017 / \\
2018\end{array}$ \\
\hline $\begin{array}{l}\text { SED } \\
\text { Program }\end{array}$ & 980.484 & 1.442 .492 & - & - & - \\
\hline Factory & 42.627 & 743.325 & - & - & - \\
\hline $\begin{array}{l}\text { Agriculture/ } \\
\text { plantation }\end{array}$ & 869.116 & 628.530 & - & - & - \\
\hline $\begin{array}{l}\text { Animal } \\
\text { Husbandary }\end{array}$ & 42.186 & 68.351 & - & - & - \\
\hline Fishery & 26.556 & 2.286 & - & - & - \\
\hline $\begin{array}{l}\text { SUPPORT } \\
\text { Program }\end{array}$ & 3.055 .103 & 2.273 .651 & - & - & - \\
\hline Education & 531.201 & 364.749 & - & - & 561.654 \\
\hline Health & 49.612 & 43.450 & - & - & 1.243 .185 \\
\hline Infrastructure & 1.798 .729 & 1.351 .345 & - & - & - \\
\hline $\begin{array}{l}\text { Village } \\
\text { Team Salary }\end{array}$ & 90.392 & 91.678 & - & - & - \\
\hline Others & 585.168 & 422.429 & - & - & - \\
\hline $\begin{array}{l}\text { Operational } \\
\text { program }\end{array}$ & 961.557 & 810.907 & - & - & - \\
\hline $\begin{array}{l}\text { 1/6 } \\
\text { Regencies }\end{array}$ & 1.818 .185 & 788.786 & - & - & - \\
\hline $\begin{array}{l}\text { Economic } \\
\text { Development }\end{array}$ & - & - & - & - & 206.923 \\
\hline $\begin{array}{l}\text { Socio- } \\
\text { cultural }\end{array}$ & - & - & - & - & 509.231 \\
\hline $\begin{array}{l}\text { Community } \\
\text { Institution }\end{array}$ & - & - & - & - & 89.385 \\
\hline $\begin{array}{l}\text { PPM Support } \\
\text { Infrastructure }\end{array}$ & - & - & - & - & 902.692 \\
\hline Total & 6.815.329 & 5.315 .836 & Unknown & 2.510 .628 & 3.513.069 \\
\hline
\end{tabular}

Source: Program Plan of PPM CSR PTNHM in 2017 
The realization of the CSR program from 2013 was USD 6,815,329; in 2014 it was USD $5,315,836$; and for 2015 there was no transparency in the amount of funds used by CSR. The local government and community around the mine do not know the amount of funds for CSR programs, in 2016/2017 amounted to USD 2,510,628 and 2017/2018 amounted to USD 3,513,069. The details of activities for 2013-2014 are divided into several parts, namely SED Program, SUPPORT Program, Operational Program and for 1/6 Regency. Details for 2017/2018 are divided into Economic Development, Social Culture, Community Institution and PPM Support Infrastructure. The following is a picture of the area around the mine financed by PTNHM CSR.

Figure 1. Area around the Mine in PTNHM CSR Assistance

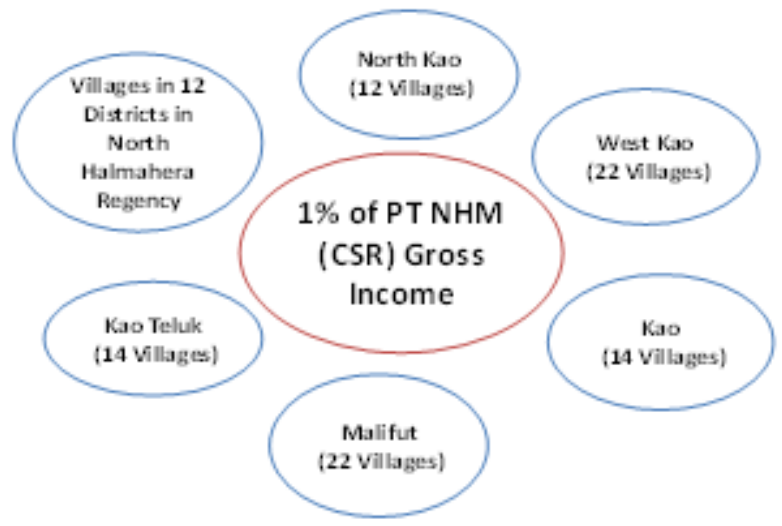

Looking at the data, it clearly defines social performance responsibilities in community development and empowerment around the mine which consists of five districts with a total of 84 villages. In addition CSR responsibilities are also for all villages in North Halmahera Regency.

\subsection{Budget Transparency of Corporate Social Responsibility}

The basis of implementing CSR is Law Number 40 of 2007 concerning limited liability companies; Article 74 paragraph 1 states that every company is obliged to carry out social responsibility; Article 2 talks about the legal consequences that will be received if CSR funds are not distributed and CSR funds constitute $1 \%$ of gross income from the company. Differences in perception then arose between PT. NHM with the community around the mine and the Government of North Halmahera Regency related to the amount of CSR funds from 2007-2017 that must be given to the community.

Stakeholders implementing the CSR program continue to strive to find solutions to the resolution of the CSR fund problem which has triggered several demonstrations. Apart from differences in views between parties who question the use of the funds, a solution that will fulfill the wishes of all stakeholders can be realized. In 2017 the Regent formally and firmly requested the PTNHM Social Performance Manager to submit all reports of CSR activities and the gross amount of PTNHM revenues from 2011-2017, because so far the local government had never known PTNMH's revenue. The North Halmahera Regency Government emphasized that the report was urgently needed to be used as a clarification material for the 
Regent, to dismiss accusations by the community surrounding the mine about the Regent regarding the approval of various programs that had been made by the Social Performance management, particularly regarding CSR programs in Education and reduction of Village Empowerment Funds around the mine from Rp250,000,000 to Rp200,000,000.

PTNHM's Social Performance Manager stated that it would provide program reports from 2011 to 2016 in January 2018. PTNHM CSR fund management was considered problematic because PT NHM was deliberately not transparent in distributing CSR funds to the community around the mine. The following shows data on the amount of $1 \%$ of the CSR funds.

Table 2. PTNH CSR 1\% BudgetM

\begin{tabular}{cc}
\hline Year & 1\% Budget Allocation (USD) \\
\hline 2007 & 1.405 .609 \\
2008 & 2.765 .521 \\
2009 & 3.185 .763 \\
2010 & 6.477 .825 \\
2011 & 4.743 .116 \\
2012 & 6.768 .451 \\
2013 & 6.815 .329 \\
2014 & 5.315 .836 \\
2015 & Unknown \\
$2016 / 2017$ & 2.510 .628 \\
$2017 / 2018$ & 3.513 .069 \\
\hline
\end{tabular}

Source : Program Plan of PPM CSR PTNHM in 2017-2018

\subsection{Debate on CSR Fund Management Rights}

Since the establishment of PTNHM in 1997, it was only in 2007 that the company provided $1 \%$ funds of the estimated gross income in a year for CSR, now known as the Community Development and Empowerment Program (PPM). It must be remembered that implementing CSR uses the principle of equal liberty and equal opportunity is very important, because the life of each individual's rights must be prioritized [7].

At the beginning of the fund management, PTNHM formed a CSR Department led by a manager. This department exists since 2007-2016. In managing the CSR budget, the CSR department's journey was not as smooth as expected because a lot of criticism came from the community around the mine related to the lack of transparency in the management of CSR budgets, causing many programs that did not meet the needs of the community. Criticism through massive demonstrations was carried out by the community to PTNHM and the Regional Government of North Halmahera Regency demanding that the CSR budget be managed directly by the community through a foundation.

Based on these demands, an agreement was reached on May 13, 2008 between representatives of the community around the mine, the Regional Government, the Regional House of Representatives, the Director General of Mineral and Coal and the President Director of PTNHM which agreed that CSR funds be managed by an independent institution "Foundation". The results of the agreement became the basis for the community around the mine to form foundations as legal entities in managing CSR funds. The local government strongly supported the establishment of independent foundations. This can be seen from the Regent's letter to the Chairman of PTNHM at Gosowong, so that in 2011 Higaro Ma Oa 
Foundation was formed. However, in the process, PT NHM was inconsistent with the "May 13" agreement which was supposed to submit CSR funds to Higaro Ma Oa Foundation. In 2012 there was a meeting between Higaro Ma Oa Foundation and PTNHM. The purpose of the meeting was that the foundation requested that PTNHM immediately submit the management of the CSR program to Higaro Ma Oa foundation. However PTNMH could not submit CSR management to the foundation. They only opened the possibility of working with foundations based on proposals for certain projects only. Demonstrations by the community around the mine continue to be carried out so that PTNHM granted the claim.

In an effort to improve CSR performance, in 2016 PTNHM formed an institution to manage CSR funds namely Social Performance. This newly formed institution did not meet the demands of the community around the mine regarding CSR funds managed by Higaro Ma Oa Foundation and even reneged on the agreement on May 13, 2008. Until now Social Performance is an institution that continues to manage CSR funds.

Looking at these dynamics, Wibisono stated that CSR is the company's responsibility to stakeholders to act ethically, minimize negative impacts, and maximize positive impacts that include economic and social aspects in order to achieve sustainable development goals [8]. Then there should be a win-win solution between the communities around the mine, PTNHM and the local government to manage CSR funds. This is intended to prevent prolonged debate between communities around the mine and PTNHM. According to Saidi and Abidin there are four models of CSR implementation patterns in Indonesia: (1) direct involvement. The company runs CSR programs directly by organizing its own social activities or submitting community contributions without intermediaries; (2) through a foundation or corporate social organization. The company establishes its own foundation under its company or group. This model is an adoption of a model commonly applied in companies in developed countries; (3) partnering with other parties. The company organizes CSR through collaboration with social institutions or non-government organizations (NGOs), Government Agencies, Universities or mass media, either in managing funds or in carrying out their social activities. (4) supporting or joining a Consortium. The company co-founded, became a member or supported a social institution established for certain social goals [9].

\section{Conclusion}

From 2007-2017, the PTNHM company gross income report was never reported to the local government and the community around the mine. This issue raised a reaction from the public and even the regional government that explicitly requested a report on the realization of the CSR budget that had not been reported to the local government so far. The realization of CSR programs is not in accordance with the needs of the community. This can be seen from many infrastructure programs that are not beneficial to the community even though they have been built with a large enough budget and empowerment programs such as economic development, socio-cultural but community institutions cannot prosper the community. The concept of community response and participation in the implementation of CSR programs is a major determinant of the program's success index, especially in programs based on independent economic development and community empowerment. Participation and initiative from the community in full and the synergy between the two parties can be a factor in optimizing program implementation. With a large gap between a large budget and the results obtained, it is necessary to design programs that are more innovative, on target and more priority on the needs of the community around the mine. 


\section{References}

[1] Erfit, "Utilization of Corporate Social Responsibility (CSR) Funds for Financing Agricultural Development in Jambi Province," J. Reg. Financ. Dev. Perspect., vol. 4, no. 3, p. 144, 2017.

[2] NRiant, Public Policy, Dynamics of Policy-Management Policy Analysis. Jakarta: PT. Elex Media Komputindo, 2011.

[3] A. Strauss and J Corbin, The basics of qualitative research. Jakarta: Pustaka Pelajar, 2005.

[4] S. Machmud, "Study the utilization of corporate social responsibility funds as an alternative source of regional development financing," J. Econ. Bus. Entrep., vol. 9, no. 1, pp. 29-44, 2015.

[5] E. Ardianto and Lvriano, Effects of Businessmanship Generosity and Multiple CSR. Jakarta: Elex Media Komputindo, 2011.

[6] S. Roza, "Planning, implementing and evaluating CSR programs (Corporate Social Responsibility)," Mankeu, vol. 3, no. 1, pp. 374-463, 2014.

[7] N. Dahlius, Putri, "Legal analysis of Corporate Social Responsibility (CSR) policies at PT Bank Sumut," USU Law J., vol. 4, no. 1, pp. 45-51, 2016.

[8] R. V. Angela, "The effectiveness of distributing funds for Corporate Social Responsibility as a form of public accountability," J. Account. Sci. Res., vol. 3, no. 6, pp. 1-15, 2014.

[9] et al Pujiyono, "Implementation of the legal responsibility model of Corporate Social Responsibility (CSR) to improve the welfare of the community," Yustisia, vol. 5, no. 1, pp. 41-51, 2016. 